
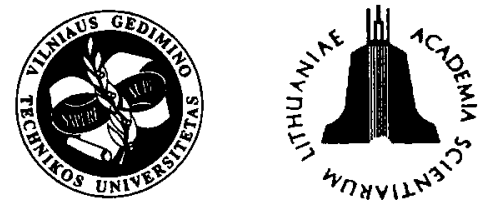

ISSN $1392-3730$

JOURNAL OF CIVIL ENGINEERING AND MANAGEMENT

http:/www.vtu.lt/english/cditions

2002, Vol VIII, No 3, 197-205

\title{
INFORMATION TECHNOLOGIES IN ENERGY PLANNING OF CITIES AND TOWNS
}

\author{
Vytautas Grigonis', Marija Burinskien $\dot{e}^{2}$ \\ Dept of Urban Engineering, Vilnius Gediminas Technical University \\ Sauletekio al. 11, LT-2040 Vilnius, Lithuania. \\ ${ }^{1}$ E-mail: Vytautas.Grigonis@ap.vtu.lt ${ }^{2}$ E-mail: Marija.Burinskiene@ap.vtu.lt
}

Received 14 June 2001; accepted 15 May 2002

\begin{abstract}
It is commonly accepted that sustainable development covers economic, social and ecological aspects and maintains vital exchange process between socioeconomic systems and natural environment. Interdisciplinary subjects emerge as a particular result of sustainable development. Energy planning is one of them. In the past inadequate technologies and inaccessible data limited many research activities. At present great progress is achieved in the fields mentioned above. The cheapest and most precise source of data the is recent register of real estate. Therefore it is possible to design a database for energy planning, where classification criteria could be selected and data could be summarized and structured according to these criteria. The possibilities to use these data would be provided in particular models. Using data processing programs could do it. Some examples are given how databases are used in energy planning and some suggestions how make necessary changes are presented in the article. It is also mentioned what kind of extra data are required to have a multidimensional database. Data are related with data processing programs in order to improve and accelerate accumulation of data. This, in turn, helps using data widely for energy planning.
\end{abstract}

Keywords: energy planning, sustainable energy system, information technologies, databases.

\section{Introduction}

In 1987, World Commission on Environment and Development approved the sustainable development conception, and now it is supported by most governments, non-governmental organizations, and representatives of business and science. Although the conception of sustainable development has been acknowledged globally, its realization is still restricted by multiple factors, the essence of which underlies in the political system [1]. The planning results are not so evident and immediate; however, the practice of Western countries indicates that selection of calculated, sustainable and democracy-based ways helps achieving good results. Sustainability is outlined by environmental, economical, as well as social criteria; and by seeking a balance point among them we try to create favourable living conditions. Sustainable energy system is also related to most planning stages with regard both to time and systems. Pursuit of such results and improved living conditions is integral to certain institutional and technological changes as well as socioeconomic decisions.

Recently, the development of Information Technologies (IT) has been influencing various activities. This influence becomes even stronger due to stiffened environmental requirements, ie endeavours to reduce energy consumption, searches for more sophisticated ways of production and consumption [2]. However, these technologies and the data compilation process are rather expensive; thus, everything should be well weighed. The Danish experience shows that transition is made from individual databases and their one-dimensional purpose to integrated and multi-functional systems, the data of which are used in various fields: starting with the real estate account and estimation and ending with the planning of individual sectors of the country. In Germany, databases are less developed and have restricted access due to a great concern about personal privacy and attempts not to set a precedent for violation of privacy rights. Meanwhile, in Great Britain huge amounts of information on buildings and land use are rapidly compiled in the digital form. Systems used mostly by commercial organizations are not integrated enough and that is of the reasoned concern to specialists, eg cases when for scientific purposes data must be compiled from different sources [3].

Modern world consumes enormous amounts of resources. World Energy Council forecasts that consumption of the primary energy will be speedily increasing (energy efficiency is taken into account) and in 2050 its consumption will increase twice as much as it is at present - 20 Gtoe [4]. Currently, the greatest energy consumer in Lithuania is household. Lithuanian housing stock covers 76 million, $\mathrm{m}^{2}$, and public buildings cover $13 \mathrm{mil}-$ 
lion, $\mathrm{m}^{2}$ and consume approximately $22 \mathrm{TWh}$ of heat [5], as much as half of which could be saved [6].

\section{The goal and the research methods}

Methodical energy planning is defined as the planning of energy resources, supply and transformation, and consumers' system using the state-of-the-art technologies. For the energy planning, it is critical to carry out the analysis (legislative, technological, etc) of the planning environment and to take into consideration priorities, commitments and foreseen changes in all sectors closely related to energy. In order to characterize present and future components of local, regional, and national energy system, a huge amount of data is necessary. Processing, arrangement, and presentation of such amount of data need information technologies. In order to work out decision trends, quality information must be used, i.e. required indicators must be singled out. Thus, it is critical to create the skeleton of the energy information system (EIS). The data characterize many segments of the energy system and the relationship among them must be arranged in the systematically structures database in a way allowing definition of the system as a whole.

The research also analyses the data sources available in Lithuania and which of them should be used (on defining the need for the data to be used in energy planning). In all states, plenty of different cadastres and registers are formed, and nowadays they are managed by the principles of geographic information systems (GIS). The application fields now including economy planning, natural resource accounting, tax planning, high quality cartography, ecological research, transport regulation, demographic research, etc are being developed in parallel with the progressive technology [7]. As it is cheaper to use the compiled data than to create new databases, these possibilities should be used in creation of EIS.

GIS technologies facilitate much the data analysis and representation. With the help of these measures, we may easily perform geographical analysis, measure distances, highlight details of interest, see links, and use mathematical models for data processing. In the field of energy planning, land and other real estate cadastre and register, as well as GIS worked out and managed at municipalities may serve as the main data sources in the energy planning; in some instances, databases of heat and electricity supply companies may also be used. However, in order to use them, it is necessary to choose classification criteria, to generalize, rearrange, and adapt the data of information systems for the energy information system.

\section{Strategic goals of the energy sector}

The Government will make every endeavour so that Lithuania is ready for the EU accession in 2004 [8]. Thus, since January 1, 2004 the Republic of Lithuania should undertake all commitments related to energy, and negotiation concerns not acquis but the terms and conditions of its implementation, ie transition periods, exclusions, and technical adaptation. Although different sections are negotiated individually, various relations among the sectors usually are equally important.

The sustainable development is based on the following main state level documents, which have already been worked out or are in the course of compiling:

- Lithuanian Economy Strategy

- The Master Plan of the Territory of the Republic of Lithuania.

State Long-Term Development Strategy, which is being actively worked out, is a strategic planning document reflecting a long-term development vision based on the analysis of economical, social-cultural, and political situation. The strategy should integrate branch strategies. The purpose of the medium-length strategy of Lithuanian economy development (till 2005) is to set the priorities of economical policy, action trends and measures for their implementation by continuing economic reforms in Lithuania and preparing for the EU membership [9].

The aim of the Master Plan of the Territory of the Republic of Lithuania is to balance the development of the country territory [10]. On the territory, usually plenty of branches of economy and various activities are being developed, thus it is essential to interrelate them, as well as to use and maintain environmental, social potential and requirements (Fig 1).

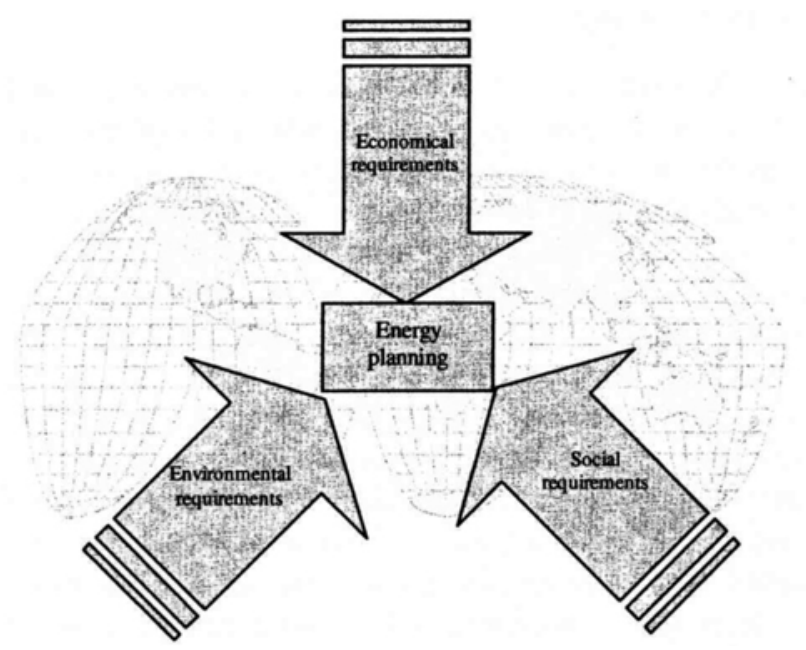

Fig 1. Requirements influencing energy planning

Naturally, the energy sector is closely related to many other branches of economy; thus, in its planning it is important to take into consideration many other factors, and to anticipate how the concluded plans will impact the environmental, social and economical sectors. Without measuring the latter primary requirements as early as in the first planning stage, the project might be doomed to failure. 
Energy planning includes planning of the energy sector, ie energy infrastructure, its layout, and sustainable development with regard to other sectors, which is so crucial for the state. The special planning [11], as a category, defines objects, structure, sets the necessary documents, as well as the procedure of their preparation, approval and coming into force. On the other hand, the energy planning is directly regulated by other laws and by-laws connected with the energy related activity, which also set special preparation procedures and methods (Fig 2).

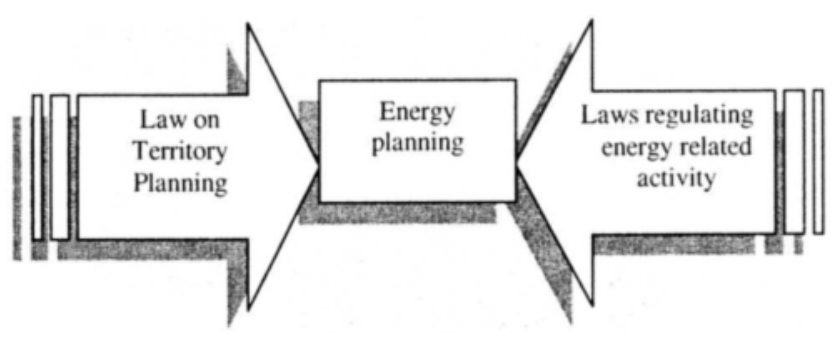

Fig 2. Regulation of energy planning in Lithuania

The main documents [12-14] regulating the energy sector and setting the planning criteria are as follows: Law on Energy, National Energy Strategy and National Energy Efficiency Programme.

Currently, 4 sectors of energy are singled out within the Republic of Lithuania (electricity, heat, gas, oil and its products). Accordingly, we might structurise the energy planning and relate each of its sectors to a certain level of planning: the electricity sector is rather the object of the national planning, the gas sector and the oil and its products sector influence both national and local systems, while the heat sector is more or less the object of local planning.

\section{Zoning of the national energy system}

Having conditionally set the functional borders between the sectors, later we will be able to draw also geographical borders. Pursuing the goals of the energy planning, any energy system being modelled and analyzed must be divided into certain geographical areas, usually basing on administrational borders, ie national, regional, or municipal. First of all, it is done for institutional reasons, as the jurisdiction of administrative bodies (government, regions, or towns) related to the energy planning is geographically defined. However, there are also other reasons why the energy planning should be attributed to controlled geographical regions of analyti- cally proper size. These reasons are incidental to the value and significance of the results of the energy system analysis. It should be mentioned that electricity flows crossing the borders of the geographical system, ie between the system and its geographical environment, and it might be much more crucial than the energy flows among the internal sub-systems of the system, irrespective of how the geographical borders are set [15].

From the technological point of view, the energy system must be analysed as the human residential and industrial system described by the internals of the energy flows. On the one hand, these systems should be designed in detail for the effective utilization of potential local and regional resources, and should exchange electricity with other systems only when it is economically and environmentally useful for the energy system of the whole region (as the entirety). But the geographical partition of the energy system and setting of its subsystems should reflect the topographical denotation of household and industrial locations.

Subject to the energy planning level, a region in the geographical terminology means the whole geographical area containing the energy system: a country, a certain region of the country, or even a smaller territory. The region might be divided into individual zones denoting a town, a group of small towns or villages, or a countryside location. Further, the zone might be divided into local systems: a certain part of the town, of a small town or a certain group of villages. The final stage is the groups of individual consumers or industrial enterprises consuming the energy.

In Lithuania, the greatest amount of the final energy is consumed by the household (Fig 3) [16].

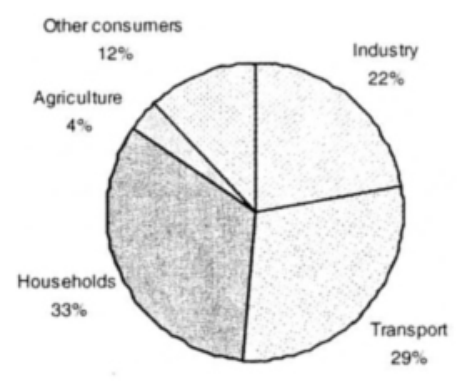

Fig 3. Consumption of the final energy (according to consumer groups in 1998)

All the above-mentioned subsystems might be analysed in a certain defined geographical region. In the arrangement of the geographical structure, elementary geographical units are called the end use systems (EUS). It could be an urban or rural location set as an elementary geographical sector and properly divided for energy planning. Existing and intended heat supply methods, especially in case of heat network or gas mains, must be considered when setting the EUS borders. The building stock formation should also be weighed: the main complex of the blocks of flats should form one EUS, the 
group of private houses should form another one. Basing on the methodology worked out by the Danish experts [17], it is proposed to single out zones (or EUS) according to the following criteria:

- Belonging to the same geographical zone;

- Being connected to the same heat/gas supply system feeder;

- Consumption of similar amount of heat [eg, MWh/ $\mathrm{m}^{2}$ ].

On finishing the geographical structurisation of the building subsystem, the places of industrial processes are being set. An individual enterprise should be connected to EUS, a local system or a zone.

The transport system consumes a lot of energy resources. Planning this subsystem, it is difficult to attach to a certain geographical zone, as a mobile consumer should be the object of the national planning. In future, with development of local energy systems and switching to the utilisation of local resources, planning at the lower level would also be expedient.

Sustainable local energy supply systems must be democratically integrated into the ecosystems of local communities. They have to merge with the biological lifetime in such way that the local biomass energy potential could be used both in urban and rural ecosystems. However, local communities, such as towns or villages, are not independent components with regard to the energy supply and demand. They are inter-connected by electricity networks and in future they will depend upon the renewable resources, such as wind or biomass fuel, which at the beginning are not referable to individual local communities [15]. Thus, designing the effective regional system containing energy interchange among local systems, cooperation among local communities within a greater region is important. Hereby, functioning of the regional system as the whole could be safeguarded.

Energy planning with regard to the regional level does not lessen the political responsibility of the state government for the provision of comprehensive economical and investment grounds for the development of sustainable energy systems. On the one hand, it is the national political responsibility for the provision of administrative and legal grounds for the energy planning on regional and local levels. On the other hand, national governments must effect the economical regulation related to energy pricing, investment funding, technical standards, such as building codes, integrity of databases and setting efficiency standards of electric appliances, environmental regulation including emission standards.

\section{Zoning of the local energy system}

Passing over to a narrower and more detailed analysis it should be stressed that a local or regional energy system may be spread in a certain geographical area, ie a city, a town, or the suburbs. Usually, an electricity network interconnects all local systems. Each local system consists of three subsystems: End Use System (EUS),
Energy Conversion and Transmission System (ECTS), and Energy Source System (ES) used in the local system [18].

In the near future laws will provide the necessity to work out special heat plans needed for shaping a longterm strategy of the territory development, and the public will be given a chance to choose a clear course of development. One of the packages under preparation at present is the Law on Heat and the methodology for its enforcement. The law and the methodology prescribe how to legally organise and perform a special planning of the energy sector.

According to the Law on the Territory Planning, state institutions, district governors, municipal boards, as well as legal entities and natural persons may act as the initiators of the energy planning. Thus, when the planning is undertaken at some of the above-mentioned state levels, the impact of the plan on the territory and inhabitants should be taken into consideration; also, the plan must be coordinated with a higher level specialist and general and detailed plans (if any).

The special energy plan is essential to the territory, as it will influence its long lifetime, ie the period of the engineering infrastructure lifetime; and in order to preserve and maintain the existing infrastructure, the territory shall be granted certain regulations. The territory regulations should protect not only against physical damage but in some cases also against insignificant changes in the market.

Usually it is considered that such planning and regulating (as zoning) is not necessary under market conditions. However, it is difficult to agree with such opinion: energy planning is a long-term process and should create a clear vision of how the society will spend its money, ie assist in the solution of the questions on the object and worth of investment, or on selection of the course. The lowest expenditure and the reliable supply might be achieved only by pursuing tough policy: planning and zoning. The goal of the zoning is to cut down expenses for the infrastructure and to maximise the employment of the system and investment.

By 2008-2012, Lithuania has to reduce emissions of greenhouse gases by $8 \%$ in comparison with 1990 [19]. The country must undertake some or other regulation, minimizing emissions, creating conditions for sustainable development: to reduce using oil products, to promote prudence, use of local resources, etc. It should first of all be performed in seeking long-term goals.

Another aspect (of concern to both consumers and authorities) is the reliability of the energy supply, as different energy supply systems are not able to give equal guarantees: gas may be supplied from Russia - a single source via pipes, oil products may be imported by seaways (various sources) and pipes from Russia, and the nuclear fuel presently imported just from Russia. Thus, pro tempore we could secure reliable supply from several sources only in the oil sector. At the local level, central heating systems are most advantageous and reli- 
able in this regard, as usually several types of fuel may be used.

Planning at the municipal level and applying zoning, we could bring coordinated competition (tender). An enterprise submitting the best alternative with regards to the National Energy Strategy, population, and environmental protection would win the competition for a certain period. Thus, it will be able to invest into the heat sector without any risk.

Foreign specialists state [20] that it is most efficient to blocks of flats and private house blocks in a centralized way, and random private buildings should be supplied with natural gas. These types of heating should be offered for selection (after efficient calculations and estimations) when planning new districts and road, water supply, sewerage, and electricity systems. These systems are no less monopolistic than the selected way of heating: all of them must be regulated by certain institutions (State Price and Energy Control Commission, Anti-Monopoly Agency). If consumers decide which system is acceptable to them and invest into it, its further replacement would be possible only in case if the vast majority assent to it, ie after public discussion of the replacement.

The most natural regulation in this case could be achieved by attracting consumers' investment into the heat sector. Consumers, having become the owners of heat networks or supply companies, could directly influence and regulate prices. Besides, consumers themselves would be concerned for reduction of the heat price and, at the same, for maintenance of the company.

\section{The structure of the energy information system}

Energy information system (EIS) (Fig 4) is the main tool in energy planning and includes databases, analysis methods, software, visualisation, data transfer. EIS is adapted to a database, energy models, GIS, and Internet. Such combination of tools enables modelling after cre-

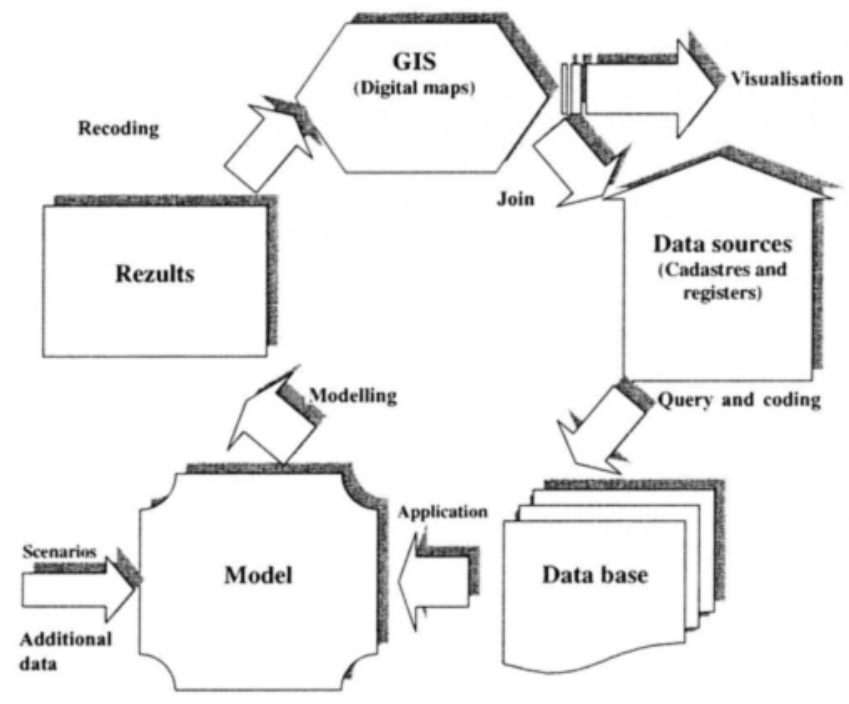

Fig 4. Data and information flows in energy planning ation of databases, results of which might be visualised and published.

Data sources may be divided into two main groups: the geodetic (cartographical) and the descriptive (text or the so-called attributive data) data. Maps and database charts are interconnected in such way that each object in the map is described in the database chart. Digital registers with the descriptive data are compiled from the existing databases containing geographical references. In most cases, references are formed according to the object coordinates or according to geographical keys address points.

Administrative-territorial partition register, address register, land and real estate cadastre and register, territory planning geodetic bank, earth entrails cadastre and forest cadastre might be useful in planning. Heat and electricity supply databases might serve as data source in the local planning.

More exact data on buildings cannot be found anywhere else but in the building register, ie separate buildings and their indicators are registered there precisely and with one accord. Describing needs for the information from other cadastres and registers in profile, administrative register would be necessary for regional system zoning; the address register would be necessary for setting belonging to a local system; the territory planning geodetic bank would be fit for the anticipation of future development tendencies in regions or smaller administrative units; and earth entrails and forest cadastres could assist in estimating local resources and tendencies of their alteration. Databases of supply enterprises might be used in modelling urban territories (using additional data sources) and estimating consumption amounts.

The energy data quality fully defines the quality of the results. Precision and data particularity are the starting point of the analysis. Precision is a number of errors in the data. Particularity means that the data amount must be sufficient for performance of the work, however economical, practical and legislative requirements must be taken into account. Naturally, the more detailed the data, the more precise analysis may be performed.

The grounds of the model consist of the energy system functioning principles, the system topology, and the above-mentioned data, which is loaded into the model (SESAM, Energy Pro, etc). The main parameters of the energy system: energy flows, according to which the energy systems that meet demand and transfer energy to electricity or heat are created [21]. The findings could be directly transferred to visualization programs.

An important aspect in the energy planning is the possibility to use geographical information systems (GIS). These are computer information systems, with the help of which geographically related data might be collected, manipulated, controlled, analysed and presented. The scope of the data is often too big and its processing needs more progressive methods. One of these methods is GIS, consisting of maps, data, and appliances used for analysis (possible hardware and software: ESRI products - Arc 
Info 8, Arc View 3.x, Arc View 8.1; Bentley Systems program complex -- Micro Station GeoGraphics; AutoDesk, Inc. - AutoCAD MAP 2000i).

With the help of GIS, different kind of work, related to energy planning, could be performed. One of the main points is different data analysis and data control. At present, energy systems in Lithuania function on the grounds of GIS, and the building sector uses GIS for administration. For example, Danish Building Register (BR) was created for tax collection and now it has become a part of the energy and environment register. With the help of BR and the address database, the energy consumption, the number of consumers connected to the central heating, etc may be calculated. In Denmark, state and public organizations must share data available to them. For efficient functioning of the system, legislation has been worked out, which safeguards certain payment. Usually, public or education institutions receive the data at a nominal price or free of charge. Meta-databases containing information on necessary data, data structure, screening, precision, prices, etc have been established to safeguard proper trade in data.
In Lithuania, creation of large-scale digital maps usually is initiated by enterprises maintaining municipal or engineering networks and concerned about this work (thus, the owners usually are town and region municipalities). However, this method for data receipt might not be employed in all parts of Lithuania, as building identification addresses necessary for GIS and building register linking are formulated fragmentarily and in many towns and municipalities they are yet being worked out, ie address point geodatabase is being created and revised. The same situation is in the field of engineering networks, boilerhouses, and power stations. While national significance objects contain small-scale GIS, the GIS of local networks and boiler-houses are only in the initial stage of fragmentary formation.

\section{Working out the energy information system}

The real estate register is established for recording real estate, property and other material rights to this property [22]. The register data are public and available to authorities and administration institutions free of charge (unless preparation is necessary); however, no possibili-

Linking of databases

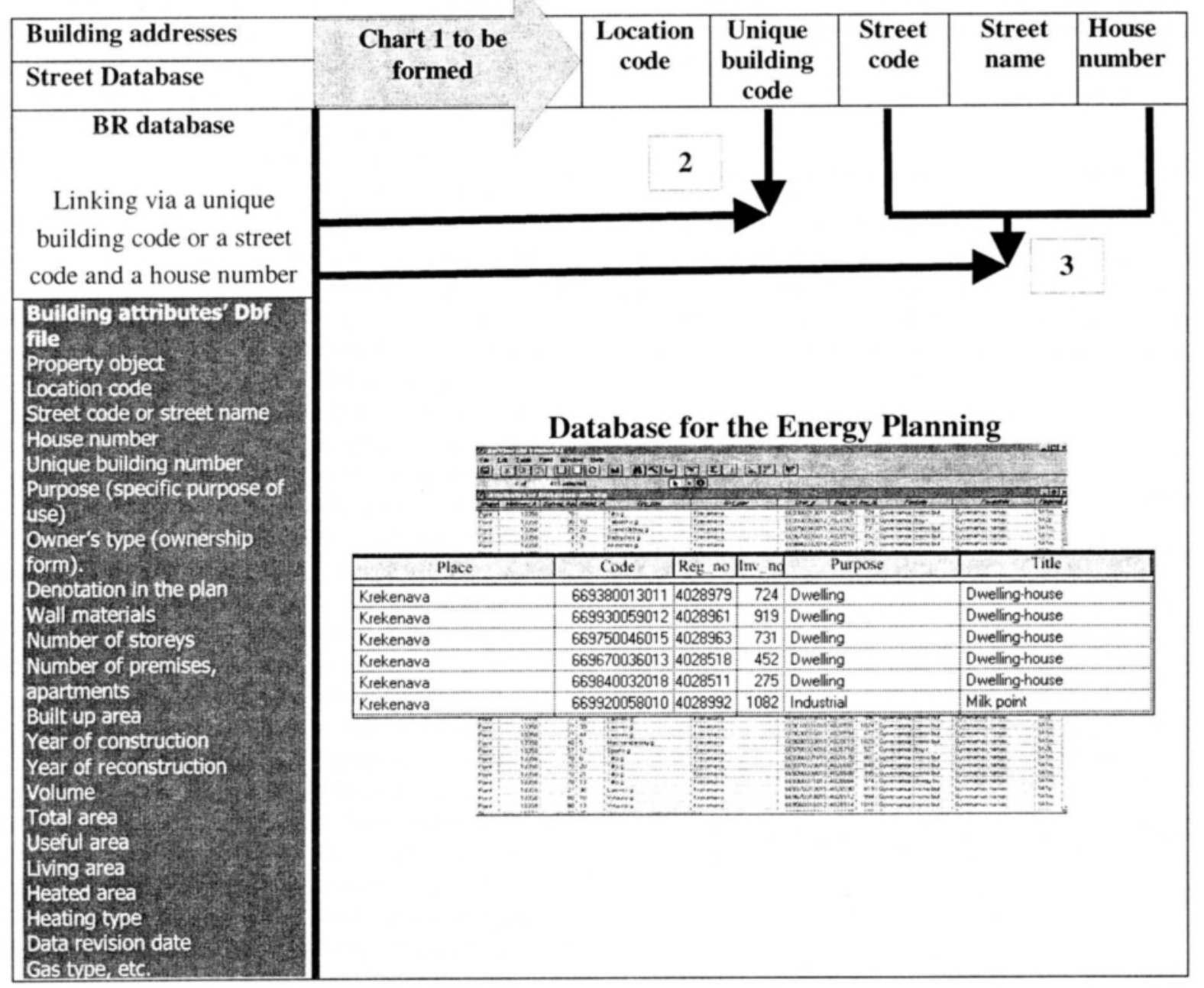


ties for academic institutions to use the data for the purpose of scientific research free of charge or at a lower cost are provided. The data bank might be connected to via Internet (having paid certain fees) and the data on each house might be received after putting an individual request; later the data may be visually revised (Žirmūnu district in Vilnius). Although the number of buildings was rather low, it turned out that the database contains errors and not all buildings are fully described.

The objects of the energy system have different geographical links and certain additional data features define that. Coordinates, addresses or references to geographically related objects may serve as a geographical link. For random objects (buildings, power stations, communication lines) coordinates matched for the coordinates of the background, ie the map may serve as geographic reference. Aggregate objects are groups of objects, for which making geographical reference is complicated (EUS). Objects are aggregated in a comprehensible way in order to identify them by descriptive data. Later, the aggregate data are geographically linked to certain features, usually to larger areas. The example is a high number of buildings that may not be identified at a certain address, however it is linked to the areas (zones) under planning.

Building register reports all structures, ie their addresses, as well as other data important with regard to the energy planning and the data of interest to the planner (Table) [23]. The energy data are kept (with direct or indirect geographical links) in attributive tables. Relational databases may keep most hierarchically grouped data on objects: heat losses, consumption, year of construction, etc. Thus we may estimate peculiarities and calculate consumption according to algorithms.

Predominant geographical link system is addresses that could be used as keys both in GIS and a database chart. The standard address consists of the numerical and text data indicating a municipality or a town, a street, a building number, an apartment number and, if any, a stairwell number. In the method of the standard addresses, one must strictly observe unique names or identifiers in each town or street.

Direct geographical references function as one-toone links among address keys. It means that each entry in the database will have an equivalent in the map, otherwise database entries will not have an equivalent in the map or the map objects will not be described. In order to safeguard conformity, we have to use common keys and formats.

In many countries, it is rather complicated to get building registers, and it is even more complicated to get data with certain links. In Denmark, the building register was developed without GIS, and only later it was fully used in GIS environment for creation of digital maps. In Lithuania, it is almost unanimously agreed that this system should be as versatile as possible and its adaptability to planning should increase [24].
Another step was to try to create such base for Krekenava town (Table). The town belonging to Panevéžys municipality has 984 buildings, 226 of which are in the former Švenčiuliškiai village, and 758 in central part of the town. Krekenava town consists of two main parts: the central part and Švenčiuliškiai village, which has been integrated into common structure of the town. Such course of history enables us to singled out the following parts with regard to building stock: more diverse buildings with regard to indicators prevail in the central part of the town, and the state is more uniform in Švenčiuliškiai village.

According to the GIS data (digital grounds) received from the municipality, we may make judgment on the geographical situation of buildings, their inter-relationship, however, sufficient information on the detailed characteristics of buildings was missing. Thus, in order to perform detailed calculations, we addressed State Land Cadastre and Register Enterprise and received compiled data on buildings. Alas, due to the fact that inventorization is no longer mandatory every 5 years, the database is not full from both qualitative and quantitative point of view. We succeeded in getting the address database containing 415 address points, 229 of which are linked to BR database. As we can see, address points are not given for all buildings (although some of them might be pertinent, etc).

Detailed database has been concluded for the buildings connected to the central heating system (Fig 5). The data on the buildings connected to the central heating were comprehensive and hardly had any errors. The remaining points described other buildings of the town (not connected to the central heating system). Premise on the buildings not described in the database was made basing on the described buildings.

Technologically, first of all an address and street chart is made, which later in two ways may be connected to the building attribute file. This file is formed independently of BR database, and later according to the existing attributes (Unique Building Code or Street Code and House Number) it is linked to the address database.

Heat consumption in buildings is determined taking into consideration heat losses through walls, floor, ceiling, and windows; the heat needed for ventilation is also considered. Physical properties of buildings are rather easily set by carrying out observation and research, however, inhabitants' behaviour is a much more complicated issue. In other words, building properties may be attributed to building groups once and inhabitants' behaviour keep changing all the time. It is especially characteristic of our society the living standards of which change speedily.

Practically, heat consumption in buildings is expressed in certain specific values: eg, heat consumption falling to a square meter of the heated area. Specific heat consumption may be calculated for a group of buildings with similar properties or inhabitants' behaviour. In 


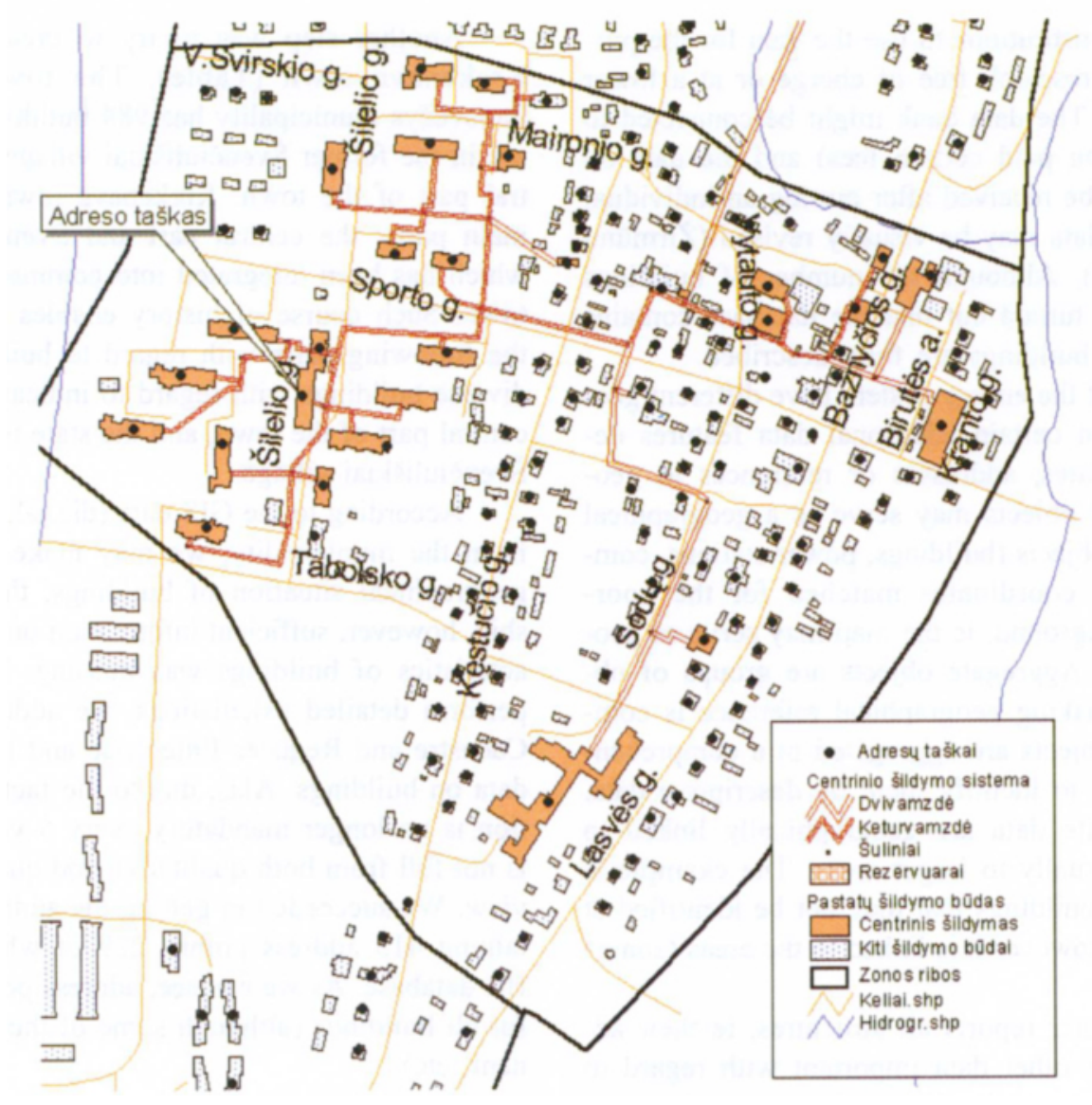

Fig 5. Energy information system for urban territory

such way, buildings are grouped according to certain types, so that the amount of the data used in the model would be reduced. Also, we may apply such building typology in other geographical fields having no physical entries (in order to save time). Having got building typology and the building set, we may group into different types. The heated area must be attributed to each building or aggregate building groups must be attributed to each type. It is one of the tasks highlighting the possibilities of GIS. In this case, the information of building groups must be organized so that a building attributed to each group would have properties and the heating area characteristic of that type.

\section{Conclusions and suggestions}

The main suggestions and conclusions for the creation of sustainable energy systems:

1. Most national programmes and strategies provide sustainable development of energy systems, which is based on planning; and its precision and success depend upon available data and tools.

2. Concluding a model, it is necessary to know an exact geographical location of consumers, ie address. Later, according to consumer's type and location with regard to gas pipes or central heating networks, EUS are formed. In all cases a map is necessary for planning (digital, ordinary or a scheme, etc).

3. State Land Cadastre and Register Enterprise is the source of most precise data. Updating and revision of the data should be carried out more speedily; also, integrity; adaptability to different fields of economy planning, administration, etc should be increased and revised.

4. Building identification addresses necessary for GIS and building register linking are not completely structured, ie address geodatabase is just under creation.

5. Databases of heat and electricity supply companies should be used with reservation, as information is compiled only on the consumers of the company without going deeper into the reasons of consumption (eg building types).

6. Taking into consideration qualitative and quantitative indicators of the data sources with regard to the energy planning, the following priority procedure is suggested:

$\checkmark$ Use of geographical information systems and cadastre and register data when the geographic system of addresses is being formed.

$\checkmark$ Use of geographical information systems and cadastre and register database when the geographical system of addresses is missing, and linking is performed using physical address. 
$\checkmark$ Use of geographical information systems and databases of heat supply enterprises when the geographical system of addresses is missing, and linking is performed using physical address.

$\checkmark$ Use of databases of cadastre and register, and heat supply enterprises when geographical zoning is performed on an ordinary map.

7. GIS consists of open-structure programmes fit for creating, filling, and updating the energy information system:

$\checkmark$ The performed dimensional analysis with regard to different attributes is speedier beyond all comparison; zoning is speedy and precise.

$\checkmark$ It enables public declaration of the data on Internet, thus the public is involved into discussions during which the vision of the energy systems crystallises.

$\checkmark$ Creation of building address database will enable easy updating of the energy databases, as the data for a specific system could be taken from real estate cadastre automatically.

8. To acknowledge and legitimate the possibility, necessity and specification of planning regional energy system development and creation of the integrated database. Standards and specifications passed at the national level, speedier arrangement of address points would facilitate the work related to the conclusion of the databases of the Energy Information System, and it would especially streamline their updating.

\section{References}

1. Seidl I. A step to endorse sustainability. International Journal of Social Economics, Vol 27, 2000, p 768-787.

2. Kincaid D. Adaptability potentials for buildings and infrastructure in sustainable cities. Journal Facilities, Vol 18, 2000, p 155-161.

3. Wyatt P. The national land and property gazetteer: addressing property properly? Journal of Property Investment and Finance, Vol 17, No 2, 1999, p 191-205.

4. World Energy Council. Energy for Tomorrow's World Acting Now, Report 2000, http://www.worldenergy.org/wec-geis/etwan/open.plx

5. Martinaitis V. Thermodynamical analysis model of building life cycle (Pastato gyvavimo ciklo termodinaminés analizès modelis). Vilnius: Technika, 2001, p 172 (in Lithuanian).

6. Modeling of Lithuanian energy strategy scenarios. Aalborg: Department of development and planning, 1999.

7. GIS. Ministry of Environment of Republic of Lithuania. Vilnius: AM, 1999 (in Lithuanian).

8. Government of Republic of Lithuania. Programme of the Government of the Republic of Lithuania for 2001-2004
(Lietuvos Respublikos Vyriausybès programa 2001 $2004 \mathrm{~m}$.), 2001. http://www.Irvk.lt/ programa/12programa.html (in Lithuanian)

9. Ministry of the Economy of Republic of Lithuania. Medium term economy strategy in the context of Lithuanian integration into $\mathrm{EU}$ (Vidutinès trukmés ekonomikos strategija Lietuvos integracijos i ES kontekste), 2001. http:/ /www.ekm.1t/catalogs/10/Ll_lietuvos_kio.htm (in Lithuanian).

10. Comprehensive plan of the territory of the Republic of Lithuania (Lieruvos Respublikos bendrasis planas), Ministry of Environment of Republic of Lithuania 2001. http:// www.aplinkuma.lt/, http://212.59.17.243/bp/ (in Lithuanian).

11. LR "Law on territorial planning" (Teritoriju planavimo istatymas), 1995 December $12^{\text {th }}$. No I-1120, Vilnius (in Lithuanian).

12. LR "Law on Energy" (Energetikos istatymas), 1995 March $28^{\text {hl. }}$. No $1-828$, Vilnius (in Lithuanian).

13. LR "National Energy Strategy" (Nacionalinè energetikos strategija), 1999 October $5^{\text {th }}$. Nr. VIII-1348, Vilnius (in Lithuanian)

14. Summary of National Energy Efficiency Programme and main implementation directions for the years 2001-2005 (Nacionalinè energijos vartojimo efektyvumo didinimo programos santrauka ir pagrindinès šios programos igyvendinimo 2001-2005 metais kryptys), 2000. http:// www3.Irs. It $/ \mathrm{cgi}$-bin/preps2?Con dition $1=150191$ (in Lithuanian).

15. Illum K. The Sustainable Energy Systems Analysis Model. Denmark: Scholin Color, 1995.

16. Primary and final energy (Pirminè ir galutinè energija). http://www.ekm.lt/catalogs/15/F911164738_16-04-05.html (in Lithuanian).

17. Ramboll. District heating decentralisation task force. Implementation of National Energy Strategy (District heating), Phase 1. CD, 2000.

18. CityPlan Prague, Czech Republic and PlanEnergi, Skorping. Denmark: Regional Energy Planning in Eastern Bohemia, The Czech Republic. Prague: Jams, 1999.

19. Kyoto protocol. http://www.unfccc.de/ resource/docs/ convkp/kpeng.pdf

20. Dyrelund A. Why zoning? Danish board of district heating, No 2, 2000, $\mathrm{p}$ 16-20.

21. Illum K. Energy system analysis. Fur: The Danish Ministry of Energy and Environment, 1997.

22. State Land Cadastre and Register Enterprise. http:// www.kada.lt/adresas.html

23. State Land Cadastre and Register Enterprise, database for Krekenava town.

24. Reform of Cadastre System in Lithuania. In: Proceeding of recommendations and conclusions (Konferencijos „Kadastro sistemos reforma Lietuvoje" rekomendacijos ir išvados). Vilnius, 2000, p 88-91 (in Lithuanian). 